\title{
STRATEGI PT. ADIKARYA DISTRIBOGA DALAM MENINGKATKAN VOLUME PENJUALAN
}

\author{
Farida Yanti Br. Simbolon \\ Paulus A. Pangemanan \\ Yolanda P.I. Rori
}

\begin{abstract}
ABSRACT
The purpose of this research was to analyze the alternative strategy to increase the volume of sales in Adikarya Distriboga Ltd Inc. The research was in September until October 2016. The primer data and secondary data were used in this research. Primer data was obtained in interview and questionnaire to four official employees. The analyzing tools of the research were Matrix Internal Factor Evaluation (IFE), Matrix External Factor Evaluation (EFE), Matrix Internal-External (IE) and analyzing SWOT (strengths, weakness, opportunities, threats). The result of this research showed that strategy of Adikarya Distriboga Ltd was in quadrant I. It was aggressive strategy (to expand marketing segment). Strategy of expanding market share can be done by opening new branches, increasing cooperation with the factory in order to always be available stock of wheat to meet demand, improve collaboration with customers, improve service good and friendly to customers and loyal to customers.
\end{abstract}

Keywords: Strategy, PT. Adikarya Distriboga, volume sales

\begin{abstract}
ABSTRAK
Penelitian bertujuan untuk menganalisis alternatif strategi PT. Adikarya Distriboga dalam meningkatkan Volume Penjualan. Penelitian ini dilaksanakan pada bulan September sampai Oktober 2016. Data yang digunakan dalam penelitian ini adalah data primer dan data sekunder. Alat analisis yang digunakan dalam menganalisis penelitian ini adalah Matrix Internal Factor Evaluation (IFE), Matrix External Factor Evaluation (EFE), Matrix Internal-External (IE) dan Analisis SWOT (Strengths, Weakness, Opportunities, Threats). Hasil penelitian menunjukan bahwa strategi PT. Adikarya Distriboga berada di kuadran I, yaitu strategi agresif (memperluas pangsa pasar). Strategi memperluas pangsa pasar dapat dilakukan dengan membuka cabang baru, meningkatkan kerjasama dengan pabrik agar selalu tersedia stok tepung terigu untuk memenuhi permintaan, meningkatkan kerjasama dengan pelanggan, meningkatkan pelayanan yang baik dan ramah terhadap pelanggan dan loyal terhadap pelanggan.
\end{abstract}

Kata kunci: strategi, PT. Adikarya Distriboga, volume penjualan

\section{PENDAHULUAN}

\section{Latar Belakang}

Setiap perusahaan, baik yang bergerak di bidang produk atau jasa, memiliki tujuan yang sama, yaitu mendapatkan keuntungan atau profit. Dalam perkembangan dunia usaha perusahaan dituntut untuk menampilkan produk yang terbaik dan dapat memenuhi daya beli konsumen. Oleh sebab itu, perusahaan harus melaksanakan pola pada manajemen yang professional dalam operasi perusahaan sehingga, perusahaan akan dapat mencapai tujuan dan perusahaan akan tetap berjalan. Salah satu langkah yang dilakukan adalah dengan meningkatkan volume penjualan. Perusahaan harus tetap hidup dan berkembang, dan selalu dapat meningkatkan volume penjualannya. Untuk itu perusahaan harus memiliki strategi, dengan memanfaatkan peluang yang ada. Strategi bagi perusahaan merupakan salah satu faktor yang sangat penting, karena strategi dalam perusahaan dapat dipergunakan sebagai pijakan dan petunjuk dalam mencapai tujuan perusahaan dalam kaitannya tujuan jangka panjang. Bahkan dengan strategi, diharapkan pemimpin atau pengelola suatu bisnis ataupun 
perusahaan dapat melakukan kegiatan bisnisnya dengan baik sehingga dapat bersaing dan mempertahankan bisnisnya diantara pesaingnya. Supranto J dan Limakrisna (2011) mengatakan bahwa dalam era globalisasi ini persaingan sangat keras. Pemasar yang akan menjual produknya berupa barang atau jasa agar bisa memenangkan persaingan harus mampu memenuhi apa yang dibutuhkan dan diinginkan para konsumennya, sehingga memberikan nilai yang lebih baik ( $a$ better consumers value). Saat ini banyak perusahaan yang menghasilkan produk atau jasa yang sejenis, untuk dapat bersaing, suatu perusahaan perlu mengenali kekuatan dan kelemahan perusahaan, serta memanfaatkan setiap peluang yang ada dan menghindari atau menimalisirkan ancaman dan kelemahan perusahaan.

Perusahaan PT. Adikarya Distriboga merupakan distributor tepung terigu di Sulawesi Utara. Perusahaan PT. Adikarya Distriboga mendistribusikan tepung terigu ke toko-toko dan pemakai langsung yaitu pabrik roti dan pabrik mie. PT. Adikarya Distriboga bekerjasama dengan PT. Eastern Pearl Flour Mills yang berlokasi di Makassar. Berikut data penjualan tepung terigu PT. Adikarya Distriboga selama 5 tahun terakhir dapat dilihat pada Tabel 1. Dapat di lihat bahwa pada tahun 2015 Tepung Terigu Gatotkaca, Kompas, Gerbang, Gerbang Mas, Gunung dan Kompas packing 10 mengalami penurunanan volume penjualan. Turunnya volume penjualan akan merugikan perusahaan. Perencanaan strategi merupakan langkah awal untuk memanfaatkan berbagai peluang yang dapat diraih dan sebagai landasan untuk memonitor perubahan-perubahan yang terjadi, sehingga dapat dilakukan penyesuain. Berdasarkan latar belakang masalah di atas maka penulis ingin meneliti 'Strategi PT. Adikarya Distriboga dalam Meningkatkan Volume Penjualan’”.

\section{Rumusan Masalah}

Berdasarkan permasalahan tersebut, maka yang menjadi masalah dalam penelitian adalah strategi apa yang tepat guna meningkatkan volume penjualan pada PT. Adikarya Distriboga

\section{.Tujuan Penelitian}

Berdasarkan latar belakang dan perumusan masalah, maka penelitian ini bertujuan untuk menganalisis alternatif strategi PT. Adikarya Distriboga dalam meningkatkan volume penjualan.

\section{Manfaat Penelitian}

Manfaat penelitian ini adalah sebagai berikut:

1. Dapat dipakai sebagai bahan masukan bagi manajemen perusahaan dalam menentukan kebijakan pada sistem pemasaran.

2. Sebagai sarana bagi penulis untuk melatih dalam meneliti suatu masalah guna mencari pemecahan masalah.

Tabel 1. Penjualan PT. Adikarya Distriboga

\begin{tabular}{llccccc}
\hline NO & $\begin{array}{c}\text { Jenis Tepung } \\
\text { Terigu }\end{array}$ & $2011(\mathrm{Kg})$ & $2012(\mathrm{Kg})$ & $2013(\mathrm{Kg})$ & $2014(\mathrm{Kg})$ & $2015(\mathrm{Kg})$ \\
& & & & & \\
\hline 1 & Gatot kaca & 8.246 .350 & 8.124 .950 & 8.270 .950 & 7.239 .250 & 5.252 .900 \\
2 & Kompas & 723.710 & 1.924 .270 & 2.746 .090 & 2.980 .260 & 1.905 .690 \\
3 & Gerbang & 390.375 & 585.975 & 550.750 & 685.550 & 569.475 \\
4 & Gerbang mas & 194.700 & 383.650 & 161.525 & 127.250 & 107.750 \\
5 & Gunung & 1.350 .550 & 1.209 .925 & 1.210 .075 & 1.391 .300 & 958.475 \\
6 & Kompas packing 10 & 723.710 & 1.924 .270 & 2.746 .090 & 2.980 .260 & 1.905 .690 \\
7 & Kompas zak & 1.809275 & 16.139 .325 & 17.147 .450 & 14.297 .975 & 1.905 .690 \\
8 & Serdadu merah & 5.781 .250 & 2.157 .500 & - & 2.142 .500 & 4.562 .500 \\
9 & Serdadu biru & - & 3.311 .875 & 2.533 .750 & 6.018 .125 & 8.376 .250 \\
\hline
\end{tabular}

Sumber: PT. Adikarya Distriboga, 2016 (diolah) 


\section{METODE PENELITIAN}

\section{Waktu dan Tempat Penelitian}

Penelitian ini dilakukan pada bulan September sampai dengan Oktober 2016. Tempat penelitian di Jl. Cereme Kp Islam 23 Manado pada PT. Adikrya Distriboga.

\section{Jenis Data}

\section{Jenis dan Sumber Data}

Jenis data yang diambil dalam penelitian ini adalah data kuantitatif dan data kualitatif.

1. Data Kuantitatif, yaitu data yang dapat dihitung atau data yang berupa angka-angka mepiputi penjualan, biaya-biaya, dan angkaangka hasil kuesioner (Syam, 2014). Data kuantitatif yang digunakan dalam penelitian ini adalah laporan penjualan dan jumlah karyawan PT. Adikarya Distriboga.

2. Data Kualitatif, yaitu data yang bersifat deskriptif atau berbentuk uraian atau penjelasan serta tidak dapat diukur dalam skala numerik. Data kualitatif dalam penelitian ini adalah struktur organisasi, job description, serta sejarah singkat berdirinya PT. Adikarya Distriboga.

\section{Sumber Data}

Sumber data yang diambil dalam penelitian ini adalah data primer.

1. Data primer adalah data yang diambil langsung dari PT. Adikarya Distriboga. Jln. Cereme Kp Islam 23 Manado. Data primer yang diperoleh langsung dari PT. Adikarya Distriboga melalui pengamatan langsung di perusahaan, wawancara dengan pihak perusahaan, dan pengisian kuesioner. Pengisian kuesioner untuk tujuan analisis strategi pemasaran dilakukan dengan memilih responden yang memiliki kontribusi besar terhadap perumusan dan pelaksanaan strategi di perusahaan. Responden yang dipilih 4 orang untuk mengisi kuesioner penelitian sebagai berikut:

a) General Manajer

b) Bagian pemasaran

c) Bagian keuangan

d) Kepala gudang

2. Data Sekunder yaitu data yang diperoleh dari perusahaan meliputi sejarah perusahaan, struktur organisasi dan laporan penjualan dari tahun 2011-2015.

\section{Konsep Pengukuran Variabel}

Adapun variabel yang diukur dalam penelitian ini yaitu sebagai berikut:

1. Kekuatan (Strength), indikator kekuatan yang diukur adalah:

a) Kualitas tepung terigu bagus

b) Tepung terigu beragam

c) Karyawan mampu menangani pelanggan yang mengeluh dengan baik

d) Lokasi usaha sesuai

e) Memiliki kendaraan operasional yang baik dan memadai

f) Adanya potongan harga

g) Citra perusaahaan yang baik

2. Kelemahan (Weakness), indikatror kelemahan yang diukur adalah:
a)Lemahnya jaringan yang langsung ke pemakai
b) Kurangnya jalinan kerjasama dengan pelanggan
c) Pengendalian stok tepung terigu masih kurang baik
d) Kurang memanfaatkan sarana promosi

3. Peluang (Opportunity), indikator peluang yang diukur adalah
a) Merek tepung terigu sudah dikenal
b) Permintaan tepung terigu tinggi
c) Memiliki kerjasama yang baik dengan pabrik
d) Harga jual dapat bersaing
e) Konsumen loyal

4. Ancaman, (Treath), indikator ancaman yang diukur adalah:
a) Banyak produk baru yang muncul dari pesaing dengan harga yang murah
b) Banyak pelanggan yang beralih ke perusahaan lain
c) Banyak pelanggan yang mengeluh

\section{Metode Analisis Data}

Metode yang diterapkan dalam penelitian ini adalah menggunakan analisis SWOT dengan langkah-langkah sebagai berikut:

\section{Mengidentifikasi Faktor-Faktor Internal dan Eksternal Perusahaan}

Faktor-faktor strategi perusahaan terdiri dari dua (dua) faktor, yaitu faktor strategi

internal yang memiliki 2 variabel yaitu variabel kekuatan dan kelemahan, dan faktor strategi eksternal yang terdiri dari 2 variabel yaitu variabel peluang dan ancaman. 


\section{Penentuan Posisi Perusahaan}

Menentukan posisi perusahaan dengan cara memadukan kekuatan, kelemahan, peluang dan ancaman pada perusahaan sehingga dapat ditentukan titik koordinat dalam diagram SWOT. Gambar diagram analisis SWOT dapat dilihat pada gambar 1 .

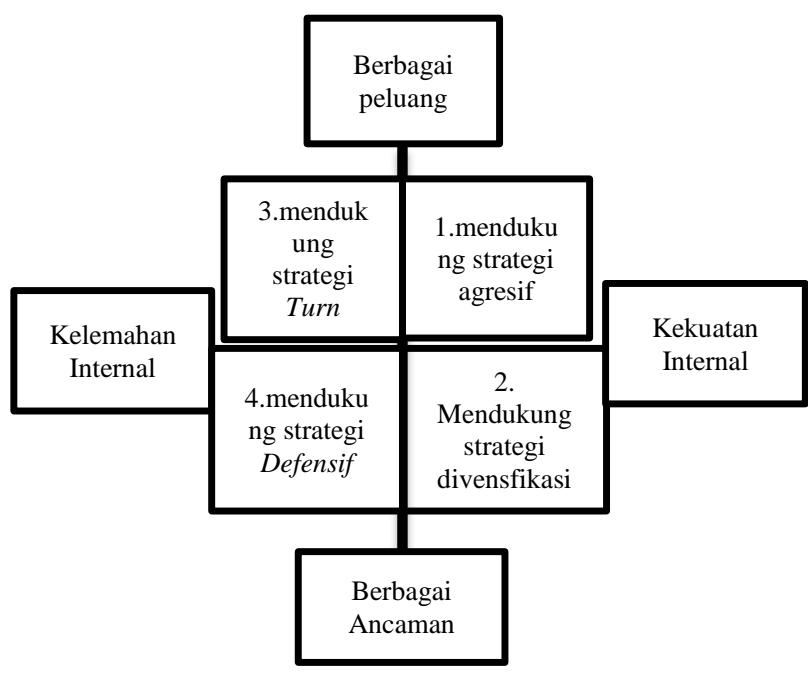

Gambar 1. Diagram Analisis SWOT

\section{Keterangan :}

Kuadaran I: Merupakan situasi yang sangat menguntungkan. Perusahaan memiliki peluang dan kekuatan. Strategi yang digunakan adalah mendukung kebijakan strategi agresif. Strategi agresif merupakan strategi perusahaan yang bertujuan untuk memperluas pasar.

Kuadaran II: Posisi ini menandakan perusahan yang kuat namun menghadapi tantangan yang besar. Rekomendasi strategi yang diberikan adalah diversifikasi strategi, artinya perusahaan memiliki kekuatan dari segi internal namun menghadapi sejumlah tantangan berat, sehingga diperkirakan roda organisasi akan mengalami kesulitan untuk terus berputar bila hanya bertumpu pada strategi sebelumnya. Oleh karenya, organisasi disarankan untuk segera memperbanyak ragam strategi.

Kuadran III: Perusahaan menghadi peluang pangsa pasar yang besar, tetapi perusahaan menghadapi kelemahan internal. Rekomendasi yang diberikan adalah turn around (ubah strategi), artinya perusaahaan disaarankan untuk mengubah strategi sebelumnya. Sebab, strategi yang lama dikhawatirkan sulit untuk dapat menangkap peluang yang ada sekaligus memperbaiki kinerja perusahaan.
Kuadaran IV: Ini adalah situasi yang sangat tidak menguntungkan bagi perusahaan. perusahaan tersebut menghadapi berbagai ancaman dan kelemahan internal. Fokus perusahaan adalah mengacu pada startegi defensif (bertahan) dan mengendalikan kinerja internal agar tidak semakin terperosok. Stratetgi ini dipertahankan sambil terus berupaya membenahi diri.

\section{Menentukan Alternatif $\quad$ Strategi Pemasaran}

Setelah mengetahui posisi perusahaan, langkah selanjutnya adalah menentukan alternatif strategi pemsaran dengan menggunakan matris SWOT. Dalam matriks SWOT akan menghasilkan penggabungan faktor-faktor strategi perusahaan yang telah teridentifikasi. Matriks SWOT dapat dilihat pada tabel 2. Dari matriks SWOT akan muncul berbagai strategi alternatif yang pada akhirnya dipilih strategi yang paling sesuai dengan kondisi dan tujuan perusahaan.

Keterangan dari matriks SWOT sebagai berikut:

a. Strategi SO ( Strenght-Opportunities)

Strategi ini dibuat berdasarkan jalan pikiran perusahaan, yaitu dengan memanfaatkan seluruh kekuatan untuk merebut dan memanfaatkan peluang sebesar-besarnya.

b. Strategi WO (Weakness-Opportinities)

Strategi ini dibuat dengan menggunakan seluruh kekuatan yang dimiliki oleh perusahaan untuk menghindari ancaman.

c. Strategi ST ( Strength-Treaths)

Strategi ini diterpakan berdasarkan pemanfaatan peluang yang ada dengan cara meminimalkan kelemahan yang ada.

d. Strategi WT (Weakness-Treaths)

Strategi ini didasarkan pada kegiatan yang bersifat defensif dan berusaha meminimalkan kelemahan yang ada serta menghindari ancaman. 
Tabel 2. Matriks SWOT

\begin{tabular}{|c|c|c|}
\hline $\begin{array}{c}\text { Faktor-faktor internal } \\
\text { (IFAS) }\end{array}$ & Kekuatan $(\mathrm{S})$ & Kelemahan $(\mathrm{W})$ \\
\hline $\begin{array}{l}\text { Faktor-faktor eksternal } \\
\text { (EFAS) }\end{array}$ & $\begin{array}{c}\text { Daftarkan 5-10 faktor-faktor } \\
\text { internal }\end{array}$ & $\begin{array}{c}\text { Daftarkan 5-10 faktor-faktor } \\
\text { eksternal }\end{array}$ \\
\hline $\begin{array}{c}\text { Peluang ( O ) } \\
\text { Daftarkan 5-10 faktor- } \\
\text { faktor peluang eksternal }\end{array}$ & $\begin{array}{c}\text { Strategi ( SO ) } \\
\text { Strategi disini yang menggunakan } \\
\text { kekuatan untuk memanfaatkan } \\
\text { peluang }\end{array}$ & $\begin{array}{c}\text { Strategi ( WO ) } \\
\text { Strategi disini yang memanfaatkan } \\
\text { peluang mengatasi ancaman }\end{array}$ \\
\hline $\begin{array}{c}\text { Ancaman ( } \mathrm{T} \text { ) } \\
\text { Daftarkan 5-10 faktor- } \\
\text { faktor ancaman eksternal }\end{array}$ & $\begin{array}{c}\text { Strategi ( ST ) } \\
\text { Strategi disini yang menggunakan } \\
\text { kekuatan untuk mengatasi } \\
\text { ancaman }\end{array}$ & $\begin{array}{c}\text { Strategi ( WT ) } \\
\text { Strategi disini yang meminimalkan } \\
\text { kelamahan dan menghindari } \\
\text { ancaman }\end{array}$ \\
\hline
\end{tabular}

Sumber : Freddy Rangkuti, 2015

\section{HASIL DAN PEMBAHASAN}

\section{Gambaran Umun PT. Adikarya Distriboga}

\section{Sejarah Singkat PT. Adikarya Distriboga}

PT. Adikarya Distriboga merupakan perusahaan perseroan terbatas yang berdiri pada tahun 2000. Perusahaan ini berdiri atas kerjasama dari beberapa pihak yang menanamkan saham mereka di perusahaan PT. Adikarya Distriboga. PT. Adikarya Distriboga adalah distributor tepung terigu dan gula pasir di Sulawesi Utara. Dalam menjalankan usaha PT. Adikarya Distriboga bekerjasama dengan PT. Eastern Pearl Flour Milss yang berlokasi di Makassar, PT. Eastern Pearl Flour Milss menggunakan gandum sebagai bahan baku dalam memproduksi tepung terigu. PT. Adikarya Distriboga mendistribusikan tepung terigu ke toko-toko, pabrik mie dan pabrik roti. Banyak jenis tepung terigu yang di tawarkan kepada konsumen, ada tepung terigu yang khusus membuat roti, tepung terigu untuk membuat mie, tepung terigu serbaguna dan tepung terigu untuk gorengan.

\section{Bauran Pemasaran PT. Adikarya Distriboga Produk (Product)}

Produk adalah merupakan sesuatu yang ditawarkan oleh perusahaan kepada konsumen yang lebih mengarah kepada kebutuhan konsumen akan produk tersebut, yang berkaitan dengan kualitas produk, serta jenis dan tipe yang bermacam-macam. Adapun jenis tepung terigu PT Adikarya Distriboga dapat dilihat pada tabel 3. Jenis tepung terigu yang paling bagus adalah tepung terigu Gerbang Mas dengan protein 14.0 dan wet gluten 35.0 kemudian gerbang protein 13.5 wet gluten 34.0 , serdadu biru protein 13.0 wet gluten 34.0, Gunung protein 13.0 wet gluten 32.0, dan Serdadu Merah protein 12.5 wet gluten 32.0.

\section{a. Jenis Tepung Terigu Protein Tinggi}

Terbuat dari gandum keras yang memiliki kadar protein $12-14 \%$, tepung ini digunakan untuk membuat roti, martabak telur, dan mie. Produk tepung terigu dengan merek gerbang mas, gerbang,gunung, serdadu biru dan serdadu merah adalah jenis tepung terigu yang tinggi protein dan merupakan tepung terigu yang paling bagus. Yang membuat adonan menjadi kenyal, elastis, dapat membentuk serat dan dapat mengembang adalah kadar gluten yang ada pada tepung terigu, semakin tinggi kadar protein yang terdapat pada tepung terigu maka makin besar kandungan glutennya.

\section{b. Jenis Tepung Terigu Protein Sedang}

Tepung terigu ini dikenal sebagai tepung serbaguna untuk segala jenis produk roti dan kue. Seluruh produk roti dan kue dapat dihasilkan dari satu jenis tepung ini. Dipasaran secara umum tepung ini dikenal dengan merek Dalam pembuatan roti, terkadang tepung ini merupakan campuran sangat minoritas dengan tepung terigu protein tinggi, namun sebenarnya tepung ini dapat digunakan tanpa campuran tepung protein tinggi. Merek tepung terigu protein sedang yaitu Kompas yang kadar proteinnya 10.5-11.5.

Untuk semua jenis tepung terigu dengan protein sedang unsur yang terkandung didalamnya semuanya sama, yang membedakan tepung terigu protein rendah adalah kemasannya yaitu ada Kompas 1 kg, Kompas Packing 10, Kompas Zak. 
Tabel 3. Jenis tepung terigu

\begin{tabular}{lccccc} 
No & $\begin{array}{c}\text { Jenis Tepung } \\
\text { Terigu }\end{array}$ & $\begin{array}{c}\text { Protein } \\
(\% \mathrm{db})\end{array}$ & Moisture $(\%)$ & Ash $((\%$ as is $)$ & Wet Gluten $(\%$ as is $)$ \\
\hline 1 & Gerbang Mas & 14.0 & 14.2 & 0.43 & 35.0 \\
2 & Gerbang & 13.5 & 14.2 & 0.55 & 34.0 \\
3 & Gunung & 13.0 & 14.2 & 0.60 & 32.0 \\
4 & Serdadu Biru & 13.0 & 14.2 & 0.47 & 34.0 \\
5 & Serdadu Merah & 12.5 & 14.2 & 0.50 & 32.0 \\
6 & Kompas & 11.5 & 14.2 & 0.60 & 29.0 \\
7 & Gatotkaca & 10.5 & 14.2 & 0.65 & 26.0 \\
\hline
\end{tabular}

Sumber: PT. Adikarya Distriboga

\section{c. Jenis Tepung Terigu Protein Rendah}

Tepung terigu ini adalah hanya khusus untuk membuat gorengan dan kue murah dan sangat tidak cocok untuk membuat roti atau kue yang bagus. Harga jual tepung ini adalah yang termurah di kelasnya Merek tepung terigu ini adalah Gatotkaca. Tepung terigu protein rendah hanya tepung terigu merek Gatotkaca, yang mana protein yang terkandung didalamnya hanya sebesar 10.5 dan wet gluten 26.0.

\section{Harga (Price)}

Harga yang ditawarkan oleh PT. Adikarya Distriboga beragam sesuai dengan jenis tepung terigu. Perusahaan menerapkan harga sama pada semua agen dan pemakai langsung. Dari daftar harga pada Tabel 4. jenis tepung terigu yang paling mahal adalah merek Kompas dengan harga Rp 8.200 sedangkan yang paling murah adalah tepung terigu dengan merek Gatotkaca.

\section{Promosi (Promotion)}

Promosi adalah suatu bentuk komunikasi pemasaran yang adalah aktivitas untuk menyebarkan informasi, mempengaruhi, dan mengingatkan pasar sasaran atas perusahaan dan produknya agar bersedia menerima, membeli, dan loyal pada produk yang ditawarkan perusahaan yang bersangkutan. Promosi yang diterapkan PT Adikarya Distriboga melalui personal selling, yaitu PT Adikarya Distriboga mempromosikan tepung terigu datang langsung ke pabrik roti dan pabrik mie dan menjelaskan keunggulan dari masing-masing jenis tepung terigu.

\section{Tempat/Distribusi (Place)}

Perusahaan menerapkan kebijakan untuk mendistribusikan tepung terigu secara langsung ke toko-toko dan pemakai langsung yaitu pabrik roti dan pabrik mie. Perusahaan bertanggung jawab untuk mengantar tepung terigu pada pelanggan.
Sumber utama keberhasilan perusahaan di masa depan adalah dukungan sumber daya manusia yang ada terhadap aktivitas perusahaan.

Sumberdaya manusia merupakan salah satu faktor internal industri yang sangat mendukung pertumbuhan industri. Saat ini PT Adikarya Distriboga memiliki 52 karyawan tetap. Dalam PT Adikarya Distriboga general manager adalah orang yang bertanggung jawab atas semua yang berhubungan dengan kegiatan perusahaan dan karyawan.

\section{Bukti Fisik (Physical Evidence)}

PT. Adikarya Distriboga berada di jalan Cereme Kp Islam 23 Manado, tempat ini sesuai dengan jenis usaha yang dijalankan. PT. Adikarya Distriboga memiliki 3 gudang yang dapat menyimpan tepung terigu sebanyak 7.500 Ton dan memiliki 7 truk untuk kendaraan operassional.

\section{Proses (Process)}

Proses merupakan nilai yang berkaitan dengan prinsip usaha untuk membuat setiap karyawan terlibat dan memiliki rasa tanggung jawab dalam proses yang memuaskan konsumen baik secara langsung maupun tidak langsung, ini dapat dilakukan pada saat penyampaian segala informasi mengenai tepung terigu ataupun dalam melayani secara langsung pada saat penjualan produk (Wulansari, 2011). Untuk mendapatkan tepung terigu pada PT. Adkarya Distriboga pelanggan bisa langsung memesan melalui telepon atau pelanggan dapat langsung datang ke perusahaan. Pelanggan yang memesan melalui telepon akan langsung diantar oleh supir. Jika pada saat jam yang sama banyak pelanggan yang memesan, perusahaan membarikan kebijakan antri, pelanggan yang memesan pertama akan dilayani terlebih dahulu. Untuk pelanggan yang jauh seperti di Talaud pelanggan datang langsung ke perusahaan untuk mendapatkan tepung terigu. 
Agri-SosioEkonomi Unsrat, ISSN 1907-4298, Volume 13 Nomor 1 A, Januari 2017 : 203 - 216

\begin{tabular}{clc}
\hline No & \multicolumn{1}{c}{ Jenis Tepung Terigu } & Harga $(\mathrm{Rp} / \mathrm{Kg})$ \\
\hline 1 & Gatot Kaca & 5.760 \\
2 & Kompas & 6.880 \\
3 & Gerbang & 7.120 \\
4 & Gerbang Mas & 7.800 \\
5 & Gunung & 7.000 \\
6 & Kompas Packing & 8.200 \\
7 & Kompas Zak & 6.880 \\
8 & Serdadu Merah & 6.600 \\
9 & Serdau Biru & 6.720 \\
\hline
\end{tabular}

Sumber: PT. Adikarya Distriboga

\section{Hasil Analisis dan Pembahasan}

\section{Mengidentifikasi Faktor-Faktor Internal dan Eksternal Perusahaan}

Data dari perusahaan PT. Adikarya Distriboga yang telah dikumpulkan maka yang menjadi kekuatan, kelemahan, peluang dan ancaman PT. Adikarya Distriboga adalah sebagai berikut:

\section{1) Kekuatan}

Kekuatan menggambarkan sesuatu yang dimiliki perusahaan yang memberikan keunggulan kompetitif bagi perusahaan. berdasarkan analisis yang dilakukan, diperoleh beberapa kekuatan yang dimiliki PT Adikarya Distriboga dalam memasarkan tepung terigu, yaitu sebagai berikut:

a. Kualitas tepung terigu bagus

Tepung terigu yang ditawarkan oleh PT Adikarya Distriboga memiliki kualitas yang bagus. Tepung terigu yang ditawarkan oleh PT Adikarya Distriboga berbahan baku gandum yang diimpor dari luar negeri diantaranya Kanada, Australia, Argentina dan Saudi Arabia. Dalam pembuatan tepung terigu, pabrik harus menggunakan biji gandum yang belum mengalami kerusakan dan biji gandum yang digiling harus memenuhi standar mutu agar tepung terigu yang dihasilkan memiliki kualitas dan mutu.

b. Tepung terigu beragam

Tepung terigu yang ditawarkan PT Adikarya Distriboga beragam, ada tepung terigu yang digunakan khusus hanya membuat roti, untuk membuat mie, tepung terigu serbaguna dan tepung terigu yang hanya untuk gorengan.

Adapun merek tepung terigu yaitu Gerbang Mas, Gerbang, Gunung, Serdadu Biru, Serdadu Merah, Komaps dan Katotkaca. Dari masingmasing tepung terigu memiliki kandungan protein dan glutein yang berbeda, semakin banyak kandungan glutein yang terdapat dalam tepung terigu maka semakin baik pula kualiatas tepung terigu.

c. Lokasi usaha sesuai

PT Adikarya Distriboga berada di Jalan Kampung Islam No 23 Manado, lokasi tersebut cocok dengan jenis usaha yang dijalankan perusahaan PT Adikarya Distriboga yaitu mendistribusikan tepung terigu ke seluruh Sulawesi Utara.

d. Memiliki kendaraan operasional yang baik dan memadai

Untuk memperlancar kegitan bisnis, perusahaan harus memiliki kendaraan operasional yang baik dan memedai. PT Adikarya Distriboga adalah distributor tepung terigu yang mana dalam menjalankan bisnisnya harus memiliki kondisi kendaraan operasional yang baik dan memadai. Saat ini PT Adikarya Distriboga memiliki kendaraan operasional sebanyak 7 truk dan semua dalam kondisi yang baik.

e. Adanya potongan harga

Dengan memberikan potongan harga, maka pelanggan akan lebih tertarik untuk membeli suatu produk. PT Adikarya Distriboga memberikan potongan harga kepada pelanggan yang membeli dalam jumlah yang banyak yaitu mulai dari 500 sak. Potongan harga yang diberikan mulai dari Rp 1.000 sampai dengan Rp 2.000/ Sak. Dan pelanggan yang datang sendiri mengambil tepung terigu ke perusahaan akan diberikan potongan harga $\mathrm{Rp} 500$ sampai $\mathrm{Rp}$ 1000/ Sak.

f. Karyawan mampu menangani pelanggan yang mengeluh dengan baik

Sumber daya manusia sangat berpengaruh dalam kegiatan bisnis, sumber daya manusia atau karyawan harus mampu melaksanakan tugas dan tanggungjawabnya dengan baik, apalagi yang berhubungan langsung dengan pelanggan atau konsumen karyawan harus mampu melayani mereka dengan baik, sehingga 
pelanggan puas dengan pelayanan yang diberikan. Jika pelanggan puas dengan layanan yang diberikan oleh karyawan maka pelanggan akan loyal. Karyawan PT Adikarya Distriboga melayani pelanggan dengan baik. Jika ada pelanggan yang mengeluh tentang tepung terigu yang bermasalah seperti tepung terigu berkutu atau bergumpal, karyawan langsung merespon dengan mendatangi toko atau pabrik pelanggan yang bersangkutan, jika memang tepung terigu bermasalah maka perusahaan akan mengganti tepung terigu yang rusak tersebut dengan tepung terigu yang baru.

\section{g. Citra perusahaan baik}

PT Adikarya Distriboga selalu dapat memenuhi permintaan pelnggan akan permintaan tepung terigu, perusahaan selalu memiliki stok persediaan tepung terigu, sehingga pelanggan tidak pernah dikecewakan dengan tidak ketersediaan tepung terigu. PT Adikarya Distriboga selalu berusaha memberikan pelayanan yang terbaik bagi pelanggan, yaitu jika pelanggan tidak bisa mengambil langsung tepung terigu dari perusahaan, maka perusahaan akan mengantar tepung terigu dengan menggunakan mobil.

\section{2) Kelemahan}

Berdasarkan hasil analisis yang dilakukan, terdapat beberapa kelemahan dari PT Adikarya Distriboga, yaitu sebagai berikut:

a. Lemahnya jaringan yang langsung ke pemakai PT Adikarya Distriboga masih lemah jaringan yang langsung ke pemakai, sedangkan keuntungan yang didapatkan lebih besar dari pemakai langsung daripada Toko-toko. Lemahhya jaringan yang langsung ke pemakai dikarenakan kurangnya memanfaatkan sarana promosi sehingga konsumen tidak mengetahui manfaat dan kelebihan dari tepung terigu.

b. Kurangnya jalinan kerjasama dengan
pelanggan Jalinan kerjasama yang baik dengan pelanggan sangat penting, jika perusahaan mampu menjalin hubungan yang baik dengan pelanggan maka pelanggan akan loyal terhadap perusahaan, artinya pelanggan tidak beralih ke perusahaan lain. PT Adikarya Distriboga masih kurang dalam menjalin hubungan kerjasama dengan pelanggan. Karyawan hanya fokus dalam menjual tepung terigu.

c. Pengendalian stok tepung terigu masih kurang baik
Persediaan merupakan hal penting yang dapat memperlancar kegiatan bisnis. Persediaan yang disimpan di gudang harus di perhatikan, karena jika tidak diperhatikan maka akan menimbulkan masalah yaitu kerusakan produk. Pengendalian PT Adikarya Distriboga masih kurang baik, yang mana pelanggan mengeluh tentang tepung terigu yang berkutu dan bergumpal. Tepung terigu yang berkutu dan bergumpal dikarenakan terlalu lama di simpan di gudang. Tepung terigu yang lama tersebut bukan karena tidak laku, tetepi karena kepala gudang yang kurang memperhatikan saat tepung terigu yang baru tiba di gudang kepala gudang tidak memperhatikan buruh yang membongkar tepung terigu, sehingga buruh menyusun tepung terigu yang baru tersebut di depan tepung terigu yang sudah lama.

d. Kurang memanfaatkan sarana promosi

Salah satu faktor penting yang mempengaruhi kelancaran pemasaran suatu produk adalah promosi. PT Adikarya Distriboga masih kurang memanfaatkan sarana promosi, promosi yang dilakukan PT Adikarya Distriboga hanya melalui personal selling yaitu karyawan mendatangi pabrik roti atau pabrik mie dan menjelaskan manfaat dan keunggulan dari tepung terigu. PT. Adikarya distriboga tidak membuat iklan di internet yang mana internet sangat membantu untuk menginformasikan lokasi perusahaan dan produk apa saja yang disediakan atau di tawarkan suatu perusahaan.

\section{3) Peluang}

a. Merek tepung terigu sudah dikenal

PT Adikarya Distriboga bekrjasama dengan PT Eastren Pearl Flour Mills, perusahaan ini sudah lama berdiri yaitu sejak tahun 1972. Seiring dengan berkembangnya bisnis hingga saat ini, membuat tepung terigu yang diproduksi PTEastern Pearl Flour Mills sudah dikenal, bahkan di Sulawesi Utara PT Eastern Pearl Flour Mills menguasai pangsa pasar sebesar $70 \%$ yang artinya hampir semua masyarakat Sulawesi Utara menggunakan tepung terigu yang diproduksi oleh PT Eastern Pearl Flour Mills.

b. Permintaan tepung terigu tinggi

Perubahan gaya hidup masyarakat Sulawesi Utara yang tidak lagi menjadikan nasi sebagai satusatunya makanan pokok dan penduduk Sulawesi Utara juga meningkat yang membuat permintaan akan tepung terigu juga meningkat.

c. Memiliki kerjasama yang baik dengan pabrik Kerjasama yang telah terjalin baik tentu saja sangat berpeluang dalam menjalankan bisnis. 
PT Adikarya Distriboga memiliki jalinan kerjasama yang baik dengan pabrik. Yussi Marlene Tumewu adalah seorang pegawai yang mengetahui semua tentang PT Adikarya Distriboga mengatakan bahwa kerjasama PT Adikarya Distriboga dengan pabrik terjalin dengan baik, yang mana PT Adikarya Distriboga tidak pernah mengalami kekosongan stok tepung terigu dan pabrik memberikan kepercayaan pada perusahaan pembayaran tepung terigu yang dipesan bisa dilakukan 2 minggu atau 3 minggu setelah tepung terigu tiba di perusahaan. d. Harga jual dapat bersaing

Harga yang diterapkan oleh PT Adikarya Distriboga dapat bersaing, yaitu Perusahaan mampu menyesuaikan harga tepung terigu dengan harga umum di pasar. PT Adikarya Distriboga menetapkan harga dibawah harga tepung merek Bogasari dan di atas harga tepung merek Mila.

e. Konsumen loyal

Kualitas tepung terigu yang didistribusikan oleh PT Adikarya Distriboga sangat baik yang membuat para pelanggan tetap loyal menggunakan tepung terigu dari perusahaan tersebut. Tepung terigu yang didistribusikan tidak hanya satu jenis tetapi banyak jenis, sehingga pelanggan atau konsumen dapat memilih jenis tepung terigu yang mereka inginkan yang sesuia dengan kebutuhan mereka.

\section{4) Ancaman}

a. Banyak produk baru yang muncul dari pesaing dengan harga yang murah

PT Adikarya Distriboga merupakan distributor tepung terigu di Sulawesi Utara, perusahaan ini memiliki pesaing yaitu PT. Semarak Adikarya yang mendistribusikan tepung terigu Bogasari, PT. Ikhtiar mendistribusikan tepung terigu Mila, tepung terigu Mila merupakan tepung terigu serbaguna dan harganya relatif murah dibawah harga tepung terigu serbaguna Kompas dan Bogasari. Harga yang relatif murah dan kualitas yang sama membuat pelanggan dan konsumen lebih memilih tepung terigu Mila.

b. Banyak pelanggan yang beralih ke perusahaan lain

PT Adikarya Distriboga memiliki banyak pesaing, salah satu pesaingnya adalah PT Sari Agrotama Persada yang mana perusahaan ini mendistribusikan tepung terigu dengan merek Mila. Tepung Terigu Mila adalah tepung serbaguna yang baru, harga tepung terigu Mila lebih murah dari harga tepung terigu serbaguna merek Kompas yang di tawarkan oleh PT Adikarya Distriboga ini membuat pelanggan beralih ke perusahaan lain yaitu perusahaan yang menawarkan tepung terigu merek Mila. Yang membuat harga tepung terigu merek Mila lebih murah daripada tepung terigu merek Kompas yaitu PT Sari Agrotama Persada pajaknya masih rendah karena perusahaan ini masih baru berdiri sedangkan PT Easrtern Pearl Flour Mills sudah lama berdiri sehingga pajaknya tinggi.

c. Banyak pelanggan yang mengeluh

Adanya complain (mengeluh) dari pelanggan dapat mempengaruhi citra perusahaan. Pelanggan yang mengeluh dapat menjadi ancaman bagi perusahaan, yaitu pelanggan akan beralih ke perusahaan lain. Pelanggan mengeluh tentang tepung terigu yang rusak seperti tepung terigu yang berkutu dan bergumpal, ini dikarenakan tepung terigu terlalu lama disimpan di gudang dan kurang memperhatikan pengendalian stok tepung terigu.

\section{Matriks IFE}

Setelah melakukan identifikasi faktorfaktor kunci internal, maka dilanjutkan dengan memberikan rating dan bobot pada faktor kunci internal bertujuan untuk mengklasifikasi faktorfaktor yang menjadi kekuatan atau kelemahan perusahaan, hasil dari pemberian rating dan bobot tersebut akan menunjukan apakah faktor tersebut merupakan kekuatan yang besar atau kecil serta kelemahan besar atau kecil. Bobot menunjukan prioritas kepentingan faktor-faktor tersebut bagi perusahaan. Hasil analisis data dengan menggunakan matiks IFE menunjukan bahwa faktor yang merupakan kekuatan utama PT Adikarya Distriboga terletak pada potongan harga yang diberikan perusahaan pada pelanggan dengan perolehan skor 0.492 . Hal ini menunjukan bahwa potongan harga yang diberikan perusahaan merupakan kekuatan utama bagi PT Adikarya distriboga dalam menutupi kekurangan yang ada dapat dilihat pada Tabel 5. Adapun kelemahan utama yang dimiliki PT Adikarya Distriboga adalah kurangnya jaringan yang langsung ke pemakai dengan skor 0.146 dan kurangnya promosi yang dilakukan perusahaan dengan skor 0.156 . Berdasarkan hasil data perhitungan pada tabel IFE diperoleh total skor bobot untuk kekuatan dan kelemahan adalah 3.297. 


\section{Matriks EFE}

Lingkungan eksternal meliputi faktor-faktor di luar perusahaan yang dapat menimbulkan peluang dan ancaman bagi perusahaan. Identifikasi faktor eksternal bertujuan untuk menentukan faktor kunci apa yang menjadi peluang dan ancaman bagi perusahaan dapat dilihat pada tabel 6. Hasil analisis matriks EFE, menunjukan bahwa faktor penting yang mempengaruhi PT. Adikarya Distriboga adalah permintaan tepung terigu yang tinggi dengan dengan skor bobot 0.616. Didukung dengan jalinan kerjasama perusahaan dengan pabrik dengan skor 0.549. Ancaman yang dihadapi perusahaan, karna semakin banyaknya perusahaan yang muncul dengan produk yang sejenis dengan harga yang murah, ini membuat konsumen beralih ke perusahaan lain skornya adalah 0.057. Matriks EFE menghasilkan total skor sebesar 2.112.

\section{Penentuan Posisi Perusahaan}

Menentukan posisi perusahaan dengan cara memadukan kekuatan (strength), kelemahan (weakness), peluang (opportunities) dan ancaman (treath) sehingga dapat ditentukan titik koordinat dalam diagram SWOT.

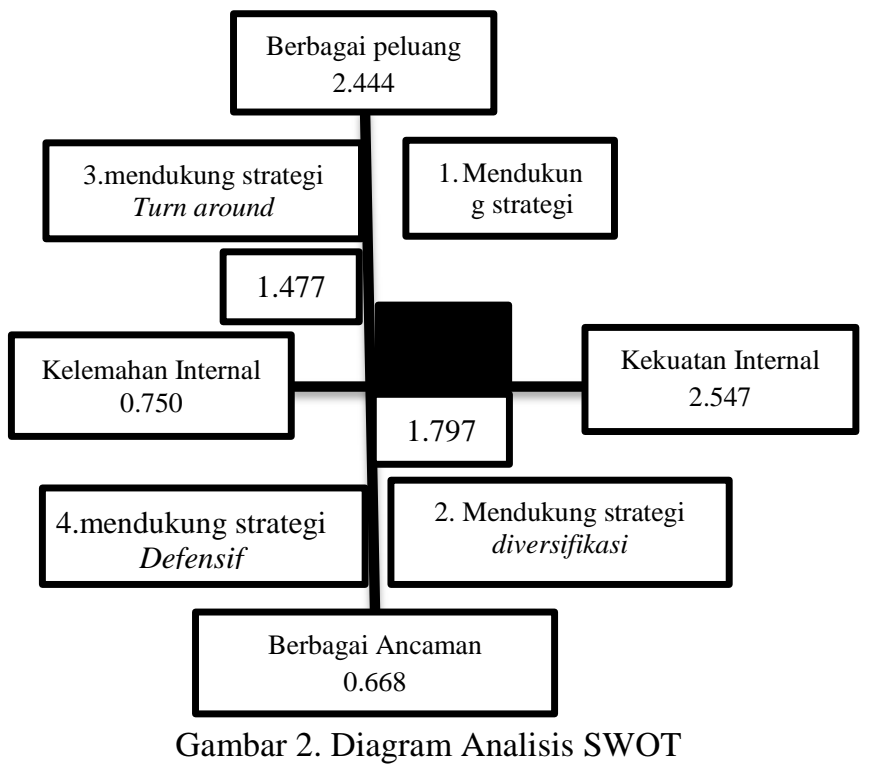

Dari gambar 2, sangat jelas menunjukan bahwa PT Adikarya Distriboga berada pada kuadran I, yaitu posisi perusahaan yang mendukung kebijakan yang agresif. Maksudnya perusahaan harus lebih giat dalam mengatasi perkembangan pasar yang kempetitif dalam rangka memperluas pangsa pasar.

\section{Menentukan Alternatif Strategi Pemasaran}

Berdasarkan hasil identifikasi dengan menggunakan matriks IFE dan EFE yang menggambarkan kekuatan dan kelemahan yang dimiliki perusahaan serta peluang dan ancaman yang dihadapi perusahaan. Dengan menggunakan matriks SWOT (Strength, Weakness, Opportunities dan Treath) dapat diperoleh alternatif strategi dengan mengkombinasikan faktor-faktor internal dan eksternal perusahaan. Matriks SWOT menghasilkan empat tipe strategi yaitu straegi SO (Strength-Opportunities), Strategi WO (Weakness-Opportunities), strategi ST (StrengthTreath) dan strategi WT (Weakness-Treath).

Dari penyusunan strategi pada matriks SWOT dihasilkan beberapa alternatif strategi antara lain sebagai berikut:

\section{Strategi SO (Strength-Opportunities)}

Meningkatkan pangsa pasar dengan tetap memberikan potongan harga, melayani pelanggan dengan baik dan ramah agar pelanggan tetap loyal dan mempertahankan citra perusahaan.

2. Strategi ST (Strength-Treath)

Meningkatkan kerjasama yang baik dengan pelanggan agar tidak beralih ke pendatang baru serta meningkatkan promosi.

\section{Strategi WO (Weakness-Opportinities)}

Meningkatkan jaringan yang langsung ke pemakai dan kerjasama dengan pelanggan dengan memanfaatkan sarana promosi dan melayani pelanggan dengan baik dan ramah.

\section{Strategi WT (Weakness-Treath)}

Memperhatikan pengendalian stok tepung terigu dengan menjual tepung terigu yang terlebih dahulu disimpan di gudang agar pelanggan tidak mengeluh atau complain.

\section{Penentuan Strategi Pemasaran}

Dari hasil alternatif strategi perusahaan yang telah diperoleh, dapat ditentukan strategi pemasaran yang sesuai dengan situasi dan kondisi serta tujuan perusahaan PT. Adikarya Distriboga yaitu meningkatkan pangsa pasar dengan membuka cabang baru, meningkatkan kerjasama dengan pabrik agar selalu tersedia tepung terigu sehingga mampu memenuhi permintaan, meningkatkan kerjasama dengan pelanggan agar pelanggan tidak beralih ke pendatang baru yaitu dengan melayani pelanggan dengan baik dan ramah karena dengan melayani pelanggan dengan baik dan ramah pelanggan akan merasa puas sehingga pelanggan tetap loyal, meningkatkan promosi dengan memanfaatkan sarana promosi 
agar konsumen banyak yang tahu lokasi perusahaan dan memperhatikan pengendalian stok tepung terigu dengan lebih dulu menjual tepung terigu yang terlebih dahulu di simpan di gudang agar tepung terigu tidak berkutu sehingga pelanggan tidak mengeluh.

\section{Tabel 5. Matriks IFE}

\begin{tabular}{|c|c|c|c|c|}
\hline No & Faktor Internal & Bobot & Rating & Skor \\
\hline \multicolumn{5}{|c|}{ Kekuatan } \\
\hline 1 & Kualitas tepung terigu bagus & 0.104 & 4.00 & 0.416 \\
\hline 2 & Tepung terigu beragam & 0.084 & 4.00 & 0.336 \\
\hline 3 & $\begin{array}{l}\text { Karyawan mampu menangani pelanggan yang } \\
\text { mengeluh dengan baik }\end{array}$ & 0.091 & 3.25 & 0.296 \\
\hline 4 & Lokasi usaha sesuai & 0.104 & 3.25 & 0.338 \\
\hline 5 & $\begin{array}{l}\text { Memiliki kendaraan operasional yang baik dan } \\
\text { memadai }\end{array}$ & 0.078 & 3.25 & 0.253 \\
\hline 6 & Memberikan potongan harga & 0.123 & 4.00 & 0.492 \\
\hline \multirow[t]{2}{*}{7} & Citra perusahaan baik & 0.104 & 4.00 & 0.416 \\
\hline & \multicolumn{4}{|l|}{ Kelemahan } \\
\hline 1 & Jaringan yang langsung ke pemakai & 0.065 & 2.25 & 0.146 \\
\hline 2 & Jalinan kerjasama perusahaan dengan pelanggan & 0.091 & 3.00 & 0.273 \\
\hline 3 & Pengendalian stok tepung terigu & 0.078 & 2.25 & 0.175 \\
\hline \multirow[t]{3}{*}{4} & Promosi yang dilakukan perusahaan & 0.078 & 2.00 & 0.156 \\
\hline & Subtotal & \multicolumn{3}{|c|}{0.750} \\
\hline & Total & 1.000 & & 3.297 \\
\hline
\end{tabular}

Tabel 6. Matriks EFE

\begin{tabular}{|c|c|c|c|c|}
\hline No & Faktor Eksternal & Bobot & Rating & Skor \\
\hline & Peluang & & & \\
\hline 1 & Merek tepung sudah dikenal & 0.148 & 3.50 & 0.518 \\
\hline 2 & Permintaan tepung terigu tinggi & 0.176 & 3.50 & 0.616 \\
\hline 3 & Jalinan kerjasama perusahaan dengan pabrik & 0.157 & 3.50 & 0.549 \\
\hline 4 & Harga jual yang kompetitif & 0.130 & 3.50 & 0.455 \\
\hline \multirow[t]{2}{*}{5} & Loyalitas pelanggan & 0.102 & 3.00 & 0.306 \\
\hline & Subtotal & & & 2.444 \\
\hline 1 & $\begin{array}{l}\text { Ancaman } \\
\text { Banyak produk baru yang muncul dari pesaing } \\
\text { dengan harga yang murah }\end{array}$ & 0.046 & 1.25 & 0.057 \\
\hline 2 & Pelanggan yang beralih ke perusahaan lain & 0.102 & 2.25 & 0.229 \\
\hline \multirow[t]{3}{*}{3} & Pelanggan yang mengeluh & 0.139 & 2.75 & 0.382 \\
\hline & Subtotal & & & 0.668 \\
\hline & Total & 1.00 & & 3.112 \\
\hline
\end{tabular}


Tabel 7. Matriks SWOT

\begin{tabular}{|c|c|c|}
\hline Eksternal & 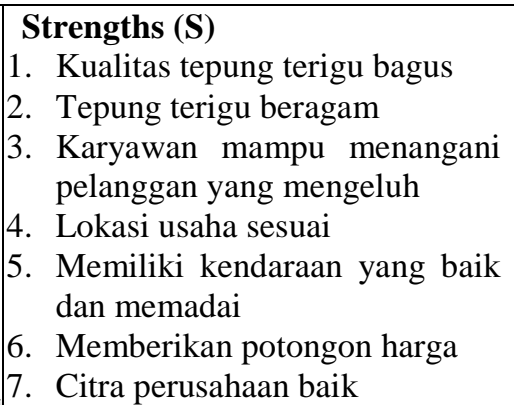 & $\begin{array}{l}\text { Weakneses }(\mathbf{W}) \\
\text { 1. Kurangnya jaringan yang langsung ke } \\
\text { pemakai } \\
\text { 2. Kurangnya jalinan kerjasama } \\
\text { perusahaan dengan pelanggan } \\
\text { 3. Pengendalian stok tepung terigu } \\
\text { kurang baik } \\
\text { 4. Promosi yang dilakukan perusahaan } \\
\text { belum maksimal }\end{array}$ \\
\hline $\begin{array}{l}\text { Opportunities }(\mathbf{O}) \\
\text { 1. Merek tepung sudah dikenal } \\
\text { 2. Permintaan tepung terigu } \\
\text { tinggi } \\
\text { 3. Terjalinnya kerjasama } \\
\text { perusahaan dengan pabrik } \\
\text { 4. Harga jual dapat bersaing } \\
\text { 5. Pelanggan loyal }\end{array}$ & $\begin{array}{l}\text { Strategi SO } \\
\text { Meningkatkan pangsa pasar } \\
\text { dengan tetap memberikan } \\
\text { potongan harga, melayani } \\
\text { pelanggan dengan baik dan ramah } \\
\text { agar pelanggan tetap loyal dan } \\
\text { mempertahankan } \\
\text { perusahaan. }\end{array}$ & $\begin{array}{l}\text { Strategi WO } \\
\text { Meningkatkan jaringan yang langsung ke } \\
\text { pemakai dan kerjasama dengan } \\
\text { pelanggan dengan memanfaatkan sarana } \\
\text { promosi dan melayani pelanggan dengan } \\
\text { baik dan ramah. }\end{array}$ \\
\hline $\begin{array}{l}\text { Treaths }(\mathbf{T}) \\
\text { 1. Banyak produk baru yang } \\
\text { muncul dari pesaing dengan } \\
\text { harga yang murah } \\
\text { 2. Banyak pelanggan yang } \\
\text { beralih ke perusahaan lain } \\
\text { 3. Banyak pelanggan yang } \\
\text { mengeluh }\end{array}$ & $\begin{array}{l}\text { Strategi ST } \\
\text { Meningkatkan kerjasama yang } \\
\text { baik dengan pelanggan agar tidak } \\
\text { beralih ke pendatang baru serta } \\
\text { meningkatkan promosi. }\end{array}$ & $\begin{array}{l}\text { Strategi WT } \\
\text { Memperhatikan pengendalian stok } \\
\text { tepung terigu dengan menjual tepung } \\
\text { terigu yang sudah lama agar pelanggan } \\
\text { tidak mengeluh atau complain. }\end{array}$ \\
\hline
\end{tabular}

\section{KESIMPULAN DAN SARAN}

\section{Kesimpulan}

Berdasarkan hasil analisis internal dan eksternal perusahaan, diperoleh strategi PT. Adikarya Distriboga berada dikuadaran I, yaitu strategi agresif memperluas pangsa pasar. Strategi memperluas pangsa pasar dapat dilakukan dengan membuka cabang baru, meningkatkan kerjasama dengan pabrik agar selalu tersedia stok tepung terigu untuk memenuhi permintaan, meningkatkan kerjasama dengan pelanggan, melayani pelanggan dengan baik dan ramah dan loyal terhadap pelanggan.

\section{Saran}

Berdasarkan kesimpulan di atas maka dapat diberikan saran untuk meningkatkan volume penjualan pada PT. Adikarya Distriboga yaitu memperluas pangsa pasar dengan memberikan potongan harga kepada pelanggan yang minimal membeli 50 sak tepung terigu dan pelanggan yang datang sendiri membeli tepung terigu di perusahaan agar konsumen lebih tertarik, meningkatkan jalinan kerjasama dengan pelanggan dan melayani pelanggan dengan baik dan ramah agar pelanggan tetap loyal artinya tidak beralih ke pendatang baru, meningkatkan promosi agar tepung terigu lebih dikenal luas, lebih memperhatikan pengendalian stok tepung terigu dengan terlebih dahulu menjual tepung terigu yang lebih dulu disimpan di gudang, agar tepung tidak berkutu sehingga pelanggan tidak mengeluh dan kecewa.

\section{DAFTAR PUSTAKA}

Abdurrahman, H Nana Herdiana. 2015. Manajemen Strategi Pemasaran. Bandung: Pustaka Setia. 
Agustini, Rina. 2007. Analisis Strategi Pemasaran 7P Obat-Obatan dan Vitamin Ternak pada PT Alco Company, Tangerang, Banten. Skripsi. Fakultas Pertanian Institut Pertanian Bogor.

Asfar, Andi Hasryningsih. 2015. Strategi Pemasaran Pakan Ternak Ayam Ras pada PT. Japfa Comfeed Indonesia Tbk Unit Makassar. Jurnal. Jurusan manajemen Sekolah Tinggi Ilmu Ekonomi Bina Bangsa Banten.

Cravens, David W. 1996. Pemasaran Strategis. Jakarta: Erlangga.

Faisal, Ahmad. 2014. Pengaruh Saluran Distribusi Terhadap Tingkat Penjualan Tiens Internasional (Stockist 212 Salahutu) Makassar. Skripsi. Fakultas Ekonomi dan Bisnis Universitas Hasanuddin Makassar.

Indriyani dan erly. 2014. Evaluasi strategi Bersaing pada PT. Triyuda Perkasa. Jurnal. Program Manajemen Bisnis Universitas Kristen Petra.

Lestari, Novi. 2010. Strategi Pemasaran Untuk Meningkatkan Volume Penjualan Pada PT. Tiga Serangkai Internasional Branch Office Surakarta. Skripsi. Fakultas Ekonomi Universitas Sebelas Maret Surakarta.

Lupiyoadi, Rambat. 2001. Manajemen Pemasaran Jasa. Jakarta: Salemba Empat.

Mappigau, Palmarudi \& Esso, A. Sawe Ri. 2011. Analisis Strategi Pemasaran Telur pada Peternakan Ayam Ras Skala Besar di Kabupaten Sidrap. Jurnal. Fakultas Peternakan Universitas Hasanuddin.
Mustamu dan Harianto. 2014. Formulasi Strategi Bersaing pada Distributor Peralatan Listrik. Jurnal. Program Manajemen Bisnis Universitas Kristen Petra.

Mustamu dan Lukito. 2013. Analisis Strategi Bersaing Pada Distributor Gula Di Indonesia. Jurnal. Program Manajemen Bisnis, Program Studi Manajemen, Universitas Kristen Petra.

Parrangan, Kumadji dan Yulianto. 2015. Analisis Strategi Perusahaan dlam Ekspansi Pasar Luar Negeri (Studi Kasus pada PT Semen Indonesia (persero) Tbk dalam Akuisisi Thang Long Coment Company di Vietnam). Jurnal. Fakultas Ilmu Administrasi Universitas Brawijaya.

Permatasari, Selfiana Nisa. 2015. Alternatif Strategi Bauran Pemasaran pada PT. Indofarma Global Medika Cabang Jember. Skripsi. Fakultas Ekonomi Universitas Jember.

Pranadi, Bot. 2006. Strategi PT. Fits Mandiri dalam Meningkatkan Pemasaran Nata De Coco. Skripsi. Fakultas Teknologi Pertaian Institut Pertanian Bogor.

Reny, Maulidia Rahmat. 2012. Analisis Strategi Pemasaran pada PT. Koko Jaya Prima Makassar. Skripsi. Fakultas Ekonomi dan Bisnis Universitas Hasanuddin.

Rosita, Santi. 2008. Analisis Strategi Usaha Sayuran Organik di PT Anugerah Bumi Persada “ RR Organic Farm”, Kabupaten Cianjur. Skripsi. Fakultas Pertanian Institut Pertanian Bogor. 
Setyawan, Robi. 2015. Penerapan Analisis SWOT Sebagai Landasan Merumuskan Strategi Pemasaran Usaha Jasa Sewa Mobil AMANAMIN Transport Tours And Travel Ambarketawang Sleman Yogyakarta. Skripsi. Fakultas Ekonomi Universitas Negeri Yogyajakarta.

Supranto \& Limakrisna. 2011. Perilaku Konsumen \& Strategi Pemasaran.jakarta: Erlangga.

Syam, Syaiful. 2014. Analisis Strategi Pemasaran Untuk Meningkatkan Penjualan Pupuk Organik Cair Pada Gapoktan. Sipakainge. Skripsi. Fakultas Peternakan Universitas Hasanuddin Makassar.
Wulansari, Dewi Richa. 2011. Strategi Pemasaran Minuman Sehat Sari Biji Nangka. Fakultas Teknik Universitas Negeri Yogyakarta. Skripsi.

Yuliawati, Surya. 2008. Analisis Strategi Pemasaran Obat Herbal Biomunos pada PT. Biofarmaka Indonesia, Bogor. Skripsi. Fakultas Pertanian Universitas Institut Pertanian Bogor. 